\title{
Scientists' Warning on Climate Change and Medicinal Plants
}

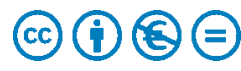

Authors

Wendy L. Applequist ${ }^{1}$, Josef A. Brinckmann ${ }^{2}$, Anthony B. Cunningham ${ }^{3}$, Robbie E. Hart ${ }^{1}$, Michael Heinrich ${ }^{4}$, David R. Katerere ${ }^{5}$, Tinde van Andel ${ }^{6}$

Affiliations

1 William L. Brown Center, Missouri Botanical Garden, St. Louis, MO, U. S. A.

2 Traditional Medicinals, Sebastopol, CA, U.S.A.

3 School of Veterinary and Life Sciences, Murdoch University, Murdoch WA, Australia

4 Pharmacognosy and Phytotherapy, UCL School of Pharmacy, University of London, London, U. K.

5 Department of Pharmaceutical Science, Tshwane University of Technology, Pretoria, R.S.A.

6 Naturalis Biodiversity Center, Leiden, The Netherlands; Biosystematics Group, Wageningen University, The Netherlands

\section{Key words}

climate change, ethnobotany, medicinal plants, sustainability, traditional knowledge, traditional medicine

received September 18, 2019

revised October 28, 2019

accepted October 30, 2019

\section{Bibliography}

DOI https://doi.org/10.1055/a-1041-3406

Published online November 15, 2019 | Planta Med 2020; 86: 10-18 @ Georg Thieme Verlag KG Stuttgart · New York ।

ISSN 0032-0943

Correspondence

Dr. Wendy Applequist

William L. Brown Center, Missouri Botanical Garden

4344 Shaw Blvd., St. Louis, MO 63110, U. S. A.

Phone: + 13145770267 , Fax: +13145770800

wendy.applequist@mobot.org
Endorsements

This article is endorsed by a number of the world's leading scientists, as detailed in the "Endorsement" section at the end.

\section{ABSTRACT}

The recent publication of a World Scientists' Warning to Humanity highlighted the fact that climate change, absent strenuous mitigation or adaptation efforts, will have profound negative effects for humanity and other species, affecting numerous aspects of life. In this paper, we call attention to one of these aspects, the effects of climate change on medicinal plants. These plants provide many benefits for human health, particularly in communities where Western medicine is unavailable. As for other species, their populations may be threatened by changing temperature and precipitation regimes, disruption of commensal relationships, and increases in pests and pathogens, combined with anthropogenic habitat fragmentation that impedes migration. Additionally, medicinal species are often harvested unsustainably, and this combination of pressures may push many populations to extinction. A second issue is that some species may respond to increased environmental stresses not only with declines in biomass production but with changes in chemical content, potentially affecting quality or even safety of medicinal products. We therefore recommend actions including conservation and local cultivation of valued plants, sustainability training for harvesters and certification of commercial material, preservation of traditional knowledge, and programs to monitor raw material quality in addition to, of course, efforts to mitigate climate change.

\section{Introduction}

In 1992, the first "World Scientists' Warning to Humanity" [1] highlighted the dangerously unsustainable rates of anthropogenic damage to the atmosphere, topsoil, forests, freshwater and ocean resources, and biodiversity overall. The 1575 signatories, including 99 Nobel laureates, called for stabilization of the human population and reduced consumption to avoid environmental catastrophes. In a recent publication entitled “World Scientists' Warn- ing to Humanity: a Second Notice" [2], a group including 15364 scientist signatories from 184 countries expressed alarm that in the years following that publication, few of the ominous trends highlighted have been adequately addressed, and most have continued to worsen. Furthermore, the first Warning to Humanity did not enumerate climate change among the major imminent threats, only noting that it was unclear whether the effects of global warming would be tolerable. It is now generally accepted that climate change is likely to cause substantial disruption to 
both natural and agricultural ecosystems, making our situation even worse than originally estimated. The Second Warning to Humanity presented up-to-date evidence for the continuing unsustainable loss of major environmental resources on which humanity depends and made broad-scale proposals for steps humanity could take to avoid environmental collapse.

In the wake of this important publication, the Alliance of World Scientists encouraged the scientific community to continue the Scientists' Warning campaign by preparing discipline-specific "Warning" papers highlighting the potential detrimental effects of climate change on specific aspects of environmental or human well-being. For example, the first Scientists' Warning disciplinespecific papers included warnings regarding the risk of significant impacts on wetlands [3], microbial communities [4], and wildfire regimes [5]. In this Warning paper, we seek to call attention to the fact that around the world, human populations' access to medicinal plants is likely to be threatened by climate change in addition to the perennial threats of direct anthropogenic habitat loss and overharvesting.

Medicinal plants are an important component of health care for most of the world's population: they constitute the primary materia medica for 70 to $95 \%$ of citizens of most developing countries and are increasingly utilized by large numbers of people residing in wealthier countries [6,7]. The contribution of medicinal plants to modern human medicine and their crucial role in traditional medicine have been documented by many authors. This is not the place to attempt to review the voluminous literature that has confirmed useful biological activities to be present in thousands of medicinal plant species, or demonstrated health benefits in human clinical trials of (minimally) hundreds of species. Suffice it to say that most of the world's people derive benefit from the use of medicinal plants (e.g., [8]), either because they are preferred to or complementary to Western (conventional) medical alternative(s) or because conventional treatments are unaffordable or inaccessible, and that those people would suffer harm from reduced or lost access to effective and affordable medicinal plants. Additionally, medicinal plants are widely used in traditional veterinary medicine (e.g., [9]), in which the improvement of livestock health has obvious benefits for their owners' economic security. Moreover, millions of people earn a living as traditional healers or collectors or vendors of medicinal plants. The harvest of and trade in medicinal plants provide an important source of income to both rural and urban people, as the global export trade value for herbal ingredients was recently estimated at over US\$32.6 billion per year [10].

Detrimental effects of climate change on medicinal plants and their users may obviously include decreases in availability, most dramatically in the extinction of species. Though the concern that access to plants will be lost through the diminution or loss of plant populations is emphasized here, it should be noted that some human populations will also be deprived of access to medicinal plants through displacement from their traditional homelands as climate refugees. A second major issue is that climate change may affect not only the accessibility and productivity of medicinal plants but the phytochemical content of surviving populations, especially of alpine plants (e.g., [11]), potentially affecting their pharmaceutical properties.

\section{Decreased Availability and Extinction of Populations}

It is well known that many plant species are or soon will be threatened with local or global extinction. A recent study reported that nearly 600 plant species have gone extinct in the past 250 years [12]. Even without climate change, wild plant populations are endangered around the world by human activities, especially habitat destruction and fragmentation (e.g., [13-16]), which create small, isolated populations that are at higher risk of local extinction (e.g., [17]). Additional threats include the introduction and spread of invasive species and exotic pathogens (e.g., [18-20]) and increased herbivory resulting from the extirpation of large predators (e.g., [21]).

High-value medicinal plants face an additional threat of unsustainable harvesting pressures. For example, the important tonic herb American ginseng (Panax quinquefolius L.), which is used for conditions including fatigue, hypertension, and upper respiratory infections [22-25], is sold in large quantities to the Chinese market. Demand is so great that illegal harvesting is a serious problem, and the species has declined over time in both abundance and average stature [26-28]. Other slow-growing medicinal plants, such as snow lotus (Saussurea laniceps Hand.-Mazz.) and goldenseal (Hydrastis canadensis L.), show similar declines in size or abundance [29-31]. At worst, commercial harvest and habitat destruction can result in the complete extinction of a valued species, as shown by the case of the North African herb silphium (probably Ferula sp.), extirpated in classical times [32, 33].

Climate change will alter environmental conditions in many localities such that they are no longer ideal - or survivable - for some species that now inhabit them. The predicted suitable range for many species, including medicinal plants, will narrow or move substantially following expected climate changes [34-39], though other species will enjoy expansions of potential range. Distributions of many organisms are already shifting rapidly towards higher latitudes or elevations [40-42], which increases competitive pressure on existing species in these ranges. Habitat fragmentation increases the risk that a species will be unable to migrate and will be driven to extinction. For some species, relationships with pollinators and other commensal organisms may be disrupted by phenological change (e.g., [43-45]). Insect populations have already been greatly reduced by human activities [46], especially habitat destruction and pollution from pesticides and other chemicals, and worsening climate change will exacerbate this problem.

Conversely, in North America, increased populations of damaging insects (particularly bark beetles) due to warmer winters, combined with the spread of fungal pathogens such as blister rust, have decimated millions of hectares of coniferous forests $[47,48]$. With continued warming, both plant diseases and exotic insect pests may increase in range (e.g., [49-51]), with newly exposed populations perhaps being particularly vulnerable (e.g., [52]). In Central Canadian black spruce [Picea mariana (Mill.) Britton, Stearns \& Pogenb.] forests, for example, the combined effects of logging, insect attacks, and fire have changed net primary productivity, carbon stocks, and soil nitrogen levels [53]. Yet in- 
teractions between insect population dynamics, climate, and wildfires due to insect-induced tree die-offs are complex, as are long-term effects of successional dynamics, highlighting the need for long-term monitoring of selected slow-growing, habitat-specific medicinal plants within these coniferous forests. It should further be kept in mind that, not only may climate change increase the damage caused by such factors as drought, fire, pests, and pathogens, but those influences may in turn increase climate change, leading to, as yet, inadequately understood but perhaps catastrophic positive feedback loops. For example, die-off or greatly reduced productivity of forest trees due to the effects of climate change could convert forests from carbon sinks into carbon sources (e.g., [54-57]), worsening climate change, which in turn would further exacerbate the factors responsible for forest die-off.

Medicinal plants will not be exempt from these effects. Examples where highly suitable habitat for a given species will clearly decrease receive the most attention (e.g., $[36,39])$, but sometimes the situation is more complex. For example, ecological niche modeling (ENM) by You et al. [37] predicted that the geographic range of Rhodiola quadrifida will contract, but the potential ranges of other Rhodiola species will expand. In contrast, Zhang et al. [58], who also used ENM, projected shrinkage of Rhodiola crenulata populations. Likewise, MaxEnt modeling of three medicinal asclepiads in Pakistan predicts that each species would both lose some of its current habitat and gain some new potential habitat [59]. Though such species may survive by spreading into newly appropriate habitats, human populations would still suffer harm if medicinally or economically important plants are lost from locally accessible lands. For example, "complete loss of habitat" was predicted for Tylophora hirsuta (Wall.) Wight, used to treat asthma and urinary retention, in parts of northern Punjab, Khyber Pakhtun Khuwa, and Baluchistan [59]. Valued medicinal plants are, likewise, among the species experiencing dramatic phenological change [60]. In addition to threatening declines in populations, phenological changes may also reduce the predictable or consistent availability of medicines to the peoples who depend upon them [61,62].

Species in montane ecosystems, and especially nival or subnival species, are at greatest risk of habitat loss (e.g., [40,63]), and future climate changes are predicted to be most severe in northern latitude mountains (e.g., [64]). Alpine meadows, among the most at-risk plant communities, can encompass both high biodiversity and a high percentage of useful plants $[65,66]$, and they are shrinking, with the warming-influenced upslope encroachment of shrubs [67]. Species growing at the highest altitudes are believed to be at greatest risk of extinction, because if they are outcompeted by the lower elevation species now extending their ranges to higher elevations, they will have "nowhere to go" [66]. As intuitive as the "nowhere to go" hypothesis may be for alpine and nival medicinal plant species, it may not be universally applicable. Loarie et al. [68] projected that (for those species that do have somewhere to go) migration may be more successful in montane areas than in flat lands due to the steeper spatial gradient of temperature change and concomitantly much lesser required migration velocity; for some species, simply moving from south-facing to north-facing slopes could permit survival.
Arid zone medicinal plants may also be at special risk. Deserts and arid shrublands are predicted to be among the biomes with the highest velocities of climate change, making compensatory migration difficult [68]. As an example, the desert steppe habitat of one of the most widely used wild medicinal plants in Chinese medicine, Glycyrrhiza uralensis Fisch., has degraded significantly in recent decades, attributed to intensifying climate change and anthropogenic disturbance [69]. The species is traditionally wild collected in China's northern autonomous regions (Inner Mongolia, Ningxia Hui, and Xinjiang Uyghur) but is now classified as an endangered and nationally protected medicinal plant species, with harvesting subject to national controls $[70,71]$. While cultivating this plant for its use in Chinese medicine had been viewed as a possible solution to declining wild populations and shortages, the content of active ingredients (e.g., glycyrrhizic acid and liquiritin) of cultivated $G$. uralensis root is considerably lower than that of mature (5-year-old) wild roots. Thus, China, a former major exporter of this species, has become a major importer in recent years to satisfy quality and quantity requirements for medicinal use [72], potentially threatening the sustainability of wild populations in arid zones of other countries now supplying China (e.g., Uzbekistan, Kazakhstan, Pakistan, Afghanistan).

Furthermore, climate change will interact additively, sometimes synergistically, and perhaps catastrophically, with other threats to medicinal plants. For example, Boswellia species, which produce the culturally and economically important resin frankincense, have already declined substantially due to factors including farmland expansion, fire, overexploitation for resin and/or wood, wood-boring beetle infestation, and intensive grazing of seedlings and young plants, resulting in adult mortality and failure of sapling recruitment [73-75]. A detailed study of 12 northern Ethiopian populations of Boswellia papyrifera Hochst. [76] concluded that if current practices continue, there will be a $50 \%$ decline in frankincense yield within 15 years and a $90 \%$ decline in both tapped and untapped populations within 50 years. If "business as usual" continues, by 2040 the stem densities of populations in the Metema and Abergelle districts are predicted to be reduced to as little as 3 and $11 \%$, respectively, of their current values [77]. Climate change could compound these predicted declines through the effects of higher fire intensities on the recruitment from seeds after periods of higher rainfall. Greater grass biomass and high fire intensity after 2 preceding years of high rainfall is well known in southern African savanna [78], but still needs to be built into predictive models for medicinal plant species in seasonally dry savannas.

Overharvesting for global consumer markets is a particular threat when combined with climate change. In North America, the extinction risk for a population of American ginseng of median size over 70 years was estimated to be $8 \%$ over 70 years with harvesting alone, $6 \%$ with climate change alone, but $65 \%$ with the two combined [28]. Inhabitants of the Colombian Andes reported that the herb Draba litamo L. Uribe, endemic to the high-altitude páramo vegetation and a revitalizing tonic traditionally claimed to convey eternal youth, was increasingly scarce due to the combination of climate change and commercial harvesting [79]. In Africa, Pterocarpus angolensis DC. is harvested not only for medicine, with the bark and roots used to treat a variety of conditions, but for do- 
mestic wood use and timber exports (particularly to South Africa and Asia [80]); other factors responsible for past population declines include habitat loss due to clearing for agriculture, and poor fire management. Climate change predictions show that Pterocarpus angolensis populations will be seriously affected in drier parts of its range (such as Namibia and Botswana [81]), while in higher rainfall portions of its range, fungal wilt disease is also affecting populations [82]. Thus, climate change, habitat loss, logging and other forms of harvest, grazing, and fire can all interact in seasonally dry African woodlands to have crushing impacts on vulnerable species.

Climate change is predicted to have negative impacts on human health, particularly by the obvious effects of increasing exposure to temperature extremes and contributing to food insecurity and poorer nutritional status (e.g., [83]). Additional indirect effects will include extending the range of vector-borne diseases such as malaria (e.g., [84,85]) and the range and sometimes potency of some toxic or allergenic plants, such as ragweed (Artemisia ambrosiifolia L. $[86,87])$; pollen counts of other species that contribute to hay fever appear already to be increasing in response to increased carbon dioxide (e.g., [88-90]). These impacts, combined with human population growth, will further increase harvesting pressure on plants used to treat the health conditions that will be exacerbated by climate change. It should be emphasized that many of the proposed means of preventing the global extinction of species in general, such as ex situ conservation and assisted migration to counter the deadly combination of rapid climate change and habitat fragmentation [91,92], though certainly of great importance, will do nothing to reduce the harm that local human populations, especially Indigenous Peoples, will suffer from decreased availability of or loss of access to economically and culturally important plants, including medicinal plants.

\section{Changes in Plant Quality or Productivity}

Even if a changing climate does not affect a given species' range, it may affect its productivity or its quality - in the case of a medicinal plant, primarily its potency or chemical composition - either positively or negatively. While variation in chemical content in food plants may also be more relevant to human health than is commonly acknowledged (e.g., [93-96]), the entire purpose for consumption or other use of medicinal plants is to derive health benefits from their bioactivities. Those bioactivities arise mainly from the plant's content of secondary metabolites, whether autogenous or produced by endophytic symbionts. Therefore, people who are deriving benefits from the use of a plant would suffer if its composition changed in a detrimental or unpredictable way. This is particularly true for consumers from traditional societies and less wealthy populations, who lack the resources to perform elaborate chemical testing to identify such changes and adjust doses to compensate. Decreased potency of a plant medicine might well go unnoticed or might be misinterpreted by a new generation of consumers as inherent lack of efficacy, leading to abandonment of useful plants.

As noted previously, both climate change and its ecological effects are predicted to be greatest in montane habitats (e.g., [11, $65,97]$ ), and plants living at the highest altitudes are feared to be at particular risk of extinction (e.g., [66]). Many high-altitude regions are occupied by populations with limited access to Western medicine, for whom botanicals are particularly important. Many medicinal species are traditionally believed to be more potent when collected from higher altitudes (e.g., [98]), and this has been confirmed for some important plants, e.g., bush tea (Athrixia phylicoides DC. [99]), chamomile (Matricaria chamomilla L. [100]), and arnica (Arnica montana L. [101]). The responsible factors are usually unknown. An experimental study of arnica found that temperature had a strong influence on chemical content [102]; contrarily, for bush tea, the correlation between altitude and chemical content does not appear to be related to temperature [99]. If montane species whose chemical content is affected by temperature migrate to higher altitudes and thereby remain in the same temperature regime, their medicinal quality will not necessarily improve, but populations that persist at their original altitudes might decline in quality. Obviously, more information is needed to understand the relationships between medicinal potency and elevation in individual species.

Expected consequences of climate change in many parts of the world include harsher weather extremes, such as more intense droughts, heavy rainfalls, heat waves, and cold snaps [84]. All of these extremes can impair growth and reproductive success of plants that are not adapted to such conditions, reducing sustainable harvest levels. However, these factors do not have consistent effects on concentrations of active metabolites. Drought stress that is not so severe as to kill plants often increases the concentration of bioactive secondary metabolites, either by decreasing biomass or by increasing actual production of the metabolites. Two recent literature reviews $[103,104]$ summarize evidence that drought stress increases the concentration of bioactive compounds in a variety of species; compound classes affected can include simple and complex phenolic compounds, essential oils and terpenes, alkaloids, and glucosinolates. In some wild plant products, such as shea butter (from Vitellaria paradoxa Gaertn.), active metabolites occur at higher levels in drier areas [105].

It is therefore possible that increased drought stress in some regions would increase the potency of some medicinal plants from those regions. However, a decrease in biomass with uncontrolled natural drought would frequently be so great as to outweigh any gains in concentration of active metabolites, even if those gains were known to consumers and the dosage was decreased to compensate. Second, sometimes chemical content is higher under water stress but lower at high temperature, e.g., in di huang (Rehmannia glutinosa (Gaertn.) Steud. [106]). If drought is accompanied by increased temperature, any beneficial effect of the former on chemical content in such species could be counteracted by the latter. High temperatures, like drought stress, may also lead to an increased concentration of secondary metabolites as a consequence of a significantly reduced biomass, as has been shown for American ginseng [107]. If people are accustomed to harvesting a certain quantity of material, either for personal use or for sale for economic subsistence, a large decline in biomass production due to drought and high temperature would result in severe economic harm and increased unsustainability of harvest levels. 
Third, increased $\mathrm{CO}_{2}$ levels may at least partially counteract the metabolic effect of drought. According to a theoretical framework outlined by Selmar and Kleinwächter [103], drought stress causes stomatal closure and reduces $\mathrm{CO}_{2}$ available to the plant, which in turn reduces the amount of $\mathrm{NADPH}+\mathrm{H}^{+}$consumed by the Calvin cycle and requires that it be consumed instead by increased production of secondary metabolites. At high atmospheric $\mathrm{CO}_{2}$ levels, the amount of $\mathrm{CO}_{2}$ available to the plant despite stomatal closure is greater, so less $\mathrm{NADPH}+\mathrm{H}^{+}$is redirected towards producing secondary metabolites. In an experimental model using sage (Salvia officinalis L.), the monoterpene concentration increased with drought stress but decreased with elevated $\mathrm{CO}_{2}$, so that when $\mathrm{CO}_{2}$ was elevated, the imposition of drought stress was necessary merely to equal the concentrations in well-watered plants at ambient $\mathrm{CO}_{2}$ [108]. It should be noted that that model is not true for all species. Most studies that have reported an increased concentration of desirable metabolites with elevated $\mathrm{CO}_{2}$ have not held other growing conditions constant. However, in controlled conditions, increasing $\mathrm{CO}_{2}$ levels led to an increased concentration of several flavonoids and phenolic compounds in ginger (Zingiber officinale Roscoe) rhizome [109] and of artemisinin in sweet Annie or qing hao (Artemisia annua L. [110]).

Finally, if in some species the concentration of plant metabolites did increase sufficiently to compensate for the reduction in harvestable biomass, this is not always a desirable effect. While the botanicals tolerated for over-the-counter sale in the West are generally safe plants, some species used in local and traditional medical systems around the world, as well as many used by formally trained practitioners, contain levels of toxic compounds that pose a real risk of harm with excessive use or use by susceptible individuals. Secondary metabolites reported to increase in concentration as a result of drought stress include toxic metabolites, e.g., pyrrolizidine alkaloids in Senecio species $[111,112]$. If these plants were to become unexpectedly more toxic due to increased environmental stress, increased harm could result. As for the changes in geographic range and phenology noted above, unpredictable shifts in a species' qualities could threaten its usability as medicine.

Effects of climate change on plants with dual use as food and medicine, which contribute to people's health through use as a staple food, are particularly important to determine. Soybean has been reported to suffer a $90 \%$ reduction in isoflavone content when grown at elevated temperatures, although the effect can be partially reversed by the addition of drought stress and elevated $\mathrm{CO}_{2}$ levels [113]. Several major oilseed crops have lower oil content when grown at higher temperatures, and the relative proportion of highly unsaturated fatty acids often decreases [114,115]. At least according to current nutritional dogma, the latter effect could worsen the nutritional quality of the extracted oils (e.g., [116-118]), potentially reducing individuals' ability to ameliorate or avoid chronic diseases, especially cardiovascular disease, by consuming healthful traditional foods. Additionally, crops in many areas affected by climate change are expected to be more vulnerable to pathogens, including mycotoxin-producing fungi (e.g., [119-122]), threatening both food security and the quality and short- and long-term safety of staple foods.
There can be no doubt that medicinal plants - like all species are affected by the multiple changes inflicted by humans on the environment, especially in highly vulnerable regions such as high mountain ecosystems. However, experimental or observational data on changes to medicinal plant populations or their phytochemical constituents and the impact of specific factors (such as the rise in $\mathrm{CO}_{2}$ or temperature and rainfall changes) on individual species remain rare. Such studies are urgently needed in order to come to a better understanding of the true impacts of climate change on medicinal and other high-value useful plants.

\section{Conclusion and Recommendations}

Increased environmental extremes and economic losses due to climate change are expected to be harmful to public health in many parts of the world, and, simultaneously, the resilience provided by access to beneficial medicinal plants is expected to decline. This may be foreseen to contribute to increased human suffering and preventable deaths if steps are not taken quickly. Ideal would be a reversal of the current trends, and, of course, we advocate strenuous efforts to mitigate climate change in order to reduce its negative effects on the biosphere and human communities worldwide. However, since it appears that mitigation, aggressive and rapid enough to entirely prevent disruptive climate change, will be politically impossible, efforts focused on adaptation to reduce the harm that will be suffered are also essential, and often can be undertaken locally. We strongly urge local and national governments, nongovernmental organizations, and the public health and ethnobotanical communities to take actions to help all communities, particularly those who depend upon medicinal plants for their health care or income, retain access to highquality traditional medicines.

Actions that may help to support medicinal plant populations include promoting the cultivation of medicinal plants in community gardens to maintain local access, preserving and respecting the value of traditional knowledge about plants and their sustainable use, training harvesters in sustainable practices. encouraging or requiring the use of certification programs for wild-collected material, especially in international commerce, and implementing urgent, large-scale conservation programs, including habitat protection. Regional phytochemical research or quality control programs that monitor biomarker content in economically important medicinal plants, especially alpine species, could identify alterations in their content and quality due to climate change, providing an opportunity to inform consumers and product manufacturers should there be a need to adjust use patterns. As last resorts, assisted migration and ex situ seedbanking may be essential to prevent permanent global extinction of useful species, but we emphasize that those measures will not reduce the harm to presentday human communities.

\section{Acknowledgements}

We thank Peter Raven, Nancy Turner, Vera De Cauwer, and William Ripple for helpful discussions, the reviewers of this manuscript for helpful suggestions, and Planta Medica for supporting its publication via open access. 


\section{Endorsements}

This paper has been endorsed by the following additional scientists and scholars: Anna Rita Bilia (University of Florence, Florence, Italy), Frans Bongers (Wageningen University, Wageningen, The Netherlands), Vera De Cauwer (Namibia University of Science and Technology, Windhoek, Namibia), Javier Echeverría (Universidad de Santiago de Chile, Santiago, Chile), Fang Zhendong (Shangri-La Alpine Botanical Garden, Shangri-La, China), Stefan Gafner (American Botanical Council, Austin, TX, U. S. A.), Suresh Ghimire (Tribhuvan University, Kirtipur, Nepal), De-An Guo (Shanghai Institute of Materia Medica, Shanghai, China), Ameenah Gurib-Fakim (CIDP Research and Innovation, Phoenix, Mauritius), Linfang Huang (Institute of Medicinal Plant Development, Chinese Academy of Medical Sciences and Peking Union Medical College, Beijing, China), Holly Johnson (American Herbal Products Association, Silver Spring, MD, U. S. A.), Rizwana Khanum (Pakistan Museum of Natural History, Islamabad, Pakistan), Aiping Lyu (School of Chinese Medicine, Hong Kong Baptist University, Hong Kong, China), Lyndy McGaw (University of Pretoria, Pretoria, South Africa), Pulok Kumar Mukherjee (Jadavpur University, Kolkata, India), Cassandra Quave (Emory University, Atlanta, GA, U.S.A.), Peter Raven (Missouri Botanical Garden, St. Louis, MO, U.S.A.), Mireia Alcántara Rodríguez (Leiden University, Leiden, The Netherlands), Judith Rollinger (University of Vienna, Vienna, Austria), Satya Sarker (Liverpool John Moores University, Liverpool, U.K.), Nancy Turner (University of Victoria, Victoria, B.C., Canada), Alvaro Viljoen (Tshwane University of Technology, Pretoria, South Africa).

\section{Conflict of Interest}

The authors declare that they have no conflict of interest.

\section{References}

[1] Union of Concerned Scientists. World Scientists' Warning to Humanity. Cambridge: Union of Concerned Scientists; 1992. Available at https:// www.ucsusa.org/about/1992-world-scientists.html\#.XD5D4ml7ncs. Accessed November 12, 2019

[2] Ripple W], Wolf C, Newsome TM, Galetti M, Alamgir M, Crist E, Mahmoud MI, Laurance WF, and 15, 364 scientist signatories from 184 countries. World Scientists' warning to humanity: a second notice. Bioscience 2017; 67: 1026-1028

[3] Finlayson CM, Davies GT, Moomaw WR, Chmura GL, Natali SM, Perry JE, Roulet N, Sutton-Grier AE. The second warning to humanity - providing a context for wetland management and policy. Wetlands 2019; 39: 1-5

[4] Cavicchioli R, Ripple WJ, Timmis KN, Azam F, Bakken LR, Baylis M, Behrenfeld M], Boetius A, Boyd PW, Classen AT, Crowther TW, Danovaro R, Foreman CM, Huisman J, Hutchins DA, Jansson JK, Karl DM, Koskella B, Welch DBM, Martiny JBH, Moran MA, Orphan V], Reay DS, Remais JV, Rich VI, Singh BK, Stein LY, Stewart FJ, Sullivan MB, van Oppen MJH, Weaver SC, Webb EA, Webster NS. Scientists' warning to humanity: microorganisms and climate change. Nat Rev Microbiol 2019; 17: 569586

[5] Coogan SCP, Robinne FN, Jain P, Flannigan MD. Scientists' warning on wildfire - a Canadian perspective. Can J For Res 2019; 49: 1015-1023

[6] World Health Organization. WHO traditional Medicine Strategy 20022005. Geneva: World Health Organization; 2002

[7] Robinson MM, Zhang X. The World Medicines Situation 2011. Traditional Medicines: global Situation, Issues and Challenges. Geneva: World Health Organization; 2011

[8] Heinrich M, Jaeger AK, eds. Ethnopharmacology. Chichester: Wiley; 2015

[9] Katerere DR, Luseba D. Ethnoveterinary botanical Medicine. Herbal Medicines for Animal Health. Boca Raton: CRC Press; 2010
[10] Brinckmann JA. Sustainable Sourcing: Markets for certified Chinese medicinal and aromatic Plants. Geneva: International Trade Centre; 2016: 22

[11] Gairola S, Shariff NM, Bhatt A, Kala CP. Influence of climate change on production of secondary chemicals in high altitude medicinal plants: issues needs immediate attention. J Med Plants Res 2010; 4: 1825-1829

[12] Humphreys AM, Govaerts R, Ficinski SZ, Lughadh EN, Vorontsova MS. Global dataset shows geography and life form predict modern plant extinction and rediscovery. Nature Ecol Evol 2019; 3: 1043-1047

[13] Skole D, Tucker C. Tropical deforestation and habitat fragmentation in the Amazon: satellite data from 1978 to 1988. Science 1993; 260: 1905-1910

[14] Riitters KH, Wickham JD, O'Neill RV, Jones KB, Smith ER, Coulston JW, Wade TG, Smith JH. Fragmentation of continental United States forests. Ecosystems 2002; 5: 815-822

[15] Harper G], Steininger MK, Tucker C], Juhn D, Hawkins F. Fifty years of deforestation and forest fragmentation in Madagascar. Environ Conserv 2007; 34: 325-333

[16] Haddad NM, Brudvig LA, Clobert J, Davies KF, Gonzalez A, Holt RD, Lovejoy TE, Sexton JO, Austin MP, Collins CD, Cook WM, Damschen El, Ewers RM, Foster BL, Jenkins CN, King AJ, Laurance WF, Levey DJ, Margules CR, Melbourne BA, Nicholls AO, Orrock JL, Song DX, Townshend JR. Habitat fragmentation and its lasting impact on Earth's ecosystems. Sci Adv 2015; 1: e1500052

[17] Matthies D, Bräuer I, Maibom W, Tscharntke T. Population size and the risk of local extinction: empirical evidence from rare plants. Oikos 2004; 105: 481-488

[18] Brasier CM. Rapid evolution of introduced plant pathogens via interspecific hybridization: Hybridization is leading to rapid evolution of Dutch elm disease and other fungal plant pathogens. Bioscience 2001; 51: 123-133

[19] Siegert NW, McCullough DG, Liebhold AM, Telewski FW. Dendrochronological reconstruction of the epicentre and early spread of emerald ash borer in North America. Divers Distrib 2014; 20: 847-858

[20] Callen ST, Miller AJ. Signatures of niche conservatism and niche shift in the North American kudzu (Pueraria montana) invasion. Divers Distrib 2015; 21: 853-863

[21] McGraw JB, Furedi MA. Deer browsing and population viability of a forest understory plant. Science 2005; 307: 920-922

[22] McElhaney JE, Simor AE, McNeil S, Predy GN. Efficacy and safety of CVTE002, a proprietary extract of Panax quinquefolius in the prevention of respiratory infections in influenza-vaccinated community-dwelling adults: a multicenter, randomized, double-blinded, and placebo-controlled trial. Influenza Res Treat 2011; 2011: 759051

[23] Seida JK, Durec T, Kuhle S. North American (Panax quinquefolius) and Asian ginseng (Panax ginseng) preparations for prevention of the common cold in healthy adults: A systematic review. Evid Based Complement Altern Med 2011; 2011: 282151

[24] Barton DL, Liu H, Dakhil SR, Linquist B, Sloan JA, Nichols CR, McGinn TW, Stella PJ, Seeger GR, Sood A, Loprinzi CL. Wisconsin Ginseng (Panax quinquefolius) to improve cancer-related fatigue: a randomized, double-blind trial, N07C2. J Natl Cancer Inst 2013; 105: 1230-1238

[25] Mucalo I, Jovanovski E, Rahelić D, Božikov V, Romić Z, Vuksan V. Effect of American ginseng (Panax quinquefolius L.) on arterial stiffness in subjects with type-2 diabetes and concomitant hypertension. J Ethnopharmacol 2013; 150: 148-153

[26] McGraw JB. Evidence for decline in stature of American ginseng plants from herbarium specimens. Biol Conserv 2001; 98: 25-32

[27] Case MA, Flinn KM, Jancaitis ], Alley A, Paxton A. Declining abundance of American ginseng (Panax quinquefolius L.) documented by herbarium specimens. Biol Conserv 2007; 134: 22-30

[28] Souther S, McGraw JB. Synergistic effects of climate change and harvest on extinction risk of American ginseng. Ecol Appl 2014; 24: 1463-1477 
[29] Mulligan MR, Gorchov DL. Population loss of goldenseal, Hydrastis canadensis L. (Ranunculaceae), in Ohio. J Torrey Bot Soc 2004; 131: 305-310

[30] Law W, Salick J. Human-induced dwarfing of Himalayan snow lotus, Saussurea laniceps (Asteraceae). Proc Natl Acad Sci U S A 2005; 102 : 10218-10220

[31] Oliver L. Hydrastis canadensis. The IUCN Red List of Threatened Species 2017: e.T44340011A44340071. Available at http://dx.doi.org/10.2305/ IUCN.UK.2017-2.RLTS.T44340011A44340071.en. Accessed November 12,2019

[32] Parejko K. Pliny the Elder's silphium: first recorded species extinction. Conserv Biol 2003; 17: 925-927

[33] Kiehn M. Silphion revisited. Med Plant Conserv 2007; 13: 4-8

[34] Shafer SL, Bartlein PJ, Thompson RS. Potential changes in the distributions of western North American tree and shrub taxa under future climate scenarios. Ecosystems 2001; 4: 200-215

[35] Pompe S, Hanspach J, Badeck F, Klotz S, Thuiller W, Kühn I. Climate and land use change impacts on plant distributions in Germany. Biol Lett 2008; 4: 564-567

[36] Guo Y, Wei H, Lu C, Gao B, Gu W. Predictions of potential geographical distribution and quality of Schisandra sphenanthera under climate change. Peer] 2016; 4: e2554

[37] You J, Qin X, Ranjitkar S, Lougheed SC, Wang M, Zhou W, Ouyang D, Zhou Y, Xu J, Zhang W, Wang Y, Yang J, Song Z. Response to climate change of montane herbaceous plants in the genus Rhodiola predicted by ecological niche modelling. Sci Rep 2018; 8: 5879

[38] Zhao Q, Li R, Gao Y, Yao Q, Guo X, Wang W. Modeling impacts of climate change on the geographic distribution of medicinal plant Fritillaria cirrhosa D. Don. Plant Biosyst 2018; 152: 349-355

[39] Abdelaal M, Fois M, Fenu G, Bacchetta G. Using MaxEnt modeling to predict the potential distribution of the endemic plant Rosa arabica Crép. in Egypt. Ecol Inform 2019; 50: 68-75

[40] Lamprecht A, Semenchuk PR, Steinbauer K, Winkler M, Pauli H. Climate change leads to accelerated transformation of high-elevation vegetation in the central Alps. New Phytol 2018; 220: 447-459

[41] Chen IC, Hill JK, Ohlemüller R, Roy DB, Thomas CD. Rapid range shifts of species associated with high levels of climate warming. Science 2011; 333: $1024-1026$

[42] Lenoir J, Svenning JC. Latitudinal and elevational Range Shifts under contemporary Climate Change. In: Levin S, ed. Encyclopedia of Biodiversity, 2nd edition. Amsterdam: Elsevier; 2013: 599-611

[43] Kudo G, Ida TY. Early onset of spring increases the phenological mismatch between plants and pollinators. Ecology 2013; 94: 2311-2320

[44] Phondani PC, Bhatt ID, Negi VS, Kothyari BP, Bhatt A, Maikhuri RK. Promoting medicinal plants cultivation as a tool for biodiversity conservation and livelihood enhancement in Indian Himalaya. J Asia-Pac Biodiv 2016; 9: 39-46

[45] Kharouba HM, Ehrlén J, Gelman A, Bolmgren K, Allen JM, Travers SE, Wolkovich EM. Global shifts in the phenological synchrony of species interactions over recent decades. Proc Natl Acad Sci U S A 2018; 115: 5211-5216

[46] Sánchez-Bayo F, Wyckhuys KAG. Worldwide decline of the entomofauna: A review of its drivers. Biol Conserv 2019; 232: 8-27

[47] Bentz B], Régnière J, Fettig C], Hansen EM, Hayes JL, Hicke JA, Kelsey RG, Negrón JF, Seybold SJ. Climate change and bark beetles of the western United States and Canada: direct and indirect effects. Bioscience 2010; 60: 602-613

[48] Amberson JT, Keville MP, Nelson CR. Effects of disturbance on tree community dynamics in whitebark pine (Pinus albicaulis Engelm.) ecosystems. Forests 2018; 9: 566

[49] Williams DW, Liebhold AM. Climate change and the outbreak ranges of two North American bark beetles. Agric Forest Entomol 2002; 4: 87-99
[50] Bergot M, Cloppet E, Pérarnaud V, Déqué M, Marçais B, Desprez-Loustau ML. Simulation of potential range expansion of oak disease caused by Phytophtora cinnamomi under climate change. Global Change Biol 2004; 10: 1539-1552

[51] Bosso L, Di Febbraro M, Cristinzio G, Zoina A, Russo D. Shedding light on the effects of climate change on the potential distribution of Xylella fastidiosa in the Mediterranean basin. Biol Invasions 2016; 18: 1759-1768

[52] Cudmore T], Björklund N, Carroll AL, Lindgren BS. Climate change and range expansion of an aggressive bark beetle: evidence of higher beetle reproduction in naïve host tree populations. J Appl Ecol 2010; 47: 10361043

[53] Chertov O, Bhatti JS, Komarov A, Mikhailov A, Bykhovets S. Influence of climate change, fire and harvest on the carbon dynamics of black spruce in Central Canada. Forest Ecol Manage 2009; 257: 941-950

[54] Kurz WA, Stinson G, Rampley G], Dymond CC, Neilson ET. Risk of natural disturbances makes future contribution of Canada's forests to the global carbon cycle highly uncertain. Proc Natl Acad Sci U S A 2008; 105: 1551 1555

[55] Nobre CA, Borma LDS. 'Tipping points' for the Amazon forest. Curr Opin Environ Sust 2009; 1: 28-36

[56] Allen CD, Macalady AK, Chenchouni H, Bachelet D, McDowell $N$ Vennetier M, Kitzberger T, Rigling A, Breshears DD, Hogg EH, Gonzalez P, Fensham R, Zhang Z, Castro J, Demidova N, Lim JH, Allard G, Running SW, Semerci A, Cobb N. A global overview of drought and heat-induced tree mortality reveals emerging climate change risks for forests. Forest Ecol Manage 2010; 259: 660-684

[57] Anderegg WRL, Schwalm C, Biondi F, Camarero J], Koch G, Litvak M, Ogle K, Shaw JD, Shevliakova E, Williams AP, Wolf A, Ziaco E, Pacala S. Pervasive drought legacies in forest ecosystems and their implications for carbon cycle models. Science 2015; 349: 528-532

[58] Zhang JZ, Zhu RW, Zhong DL, Zhang JQ. Nunataks or massif de refuge? A phylogeographic study of Rhodiola crenulata (Crassulaceae) on the world's highest sky islands. BMC Evol Biol 2018; 18: 154

[59] Khanum R, Mumtaz AS, Kumar S. Predicting impacts of climate change on medicinal asclepiads of Pakistan using Maxent modeling. Acta Oecol 2013; 49: 23-31

[60] Cavaliere $C$. The effects of climate change on medicinal and aromatic plants. HerbalGram 2008; 81: 44-57

[61] Turner NJ, Clifton H. “It's so different today": Climate change and indigenous lifeways in British Columbia, Canada. Global Environ Change 2009: 19: 180-190

[62] Ruelle ML, Kassam KAS. Diversity of plant knowledge as an adaptive asset: a case study with Standing Rock elders. Econ Bot 2011; 65: 295307

[63] Grabherr G. Biodiversity in the high ranges of the Alps: ethnobotanica and climate change perspectives. Global Environ Change 2009; 19: 167-172

[64] Nogués-Bravo D, Araújo MB, Errea MP, Martínez-Rica JP. Exposure of global mountain systems to climate warming during the 21st Century. Global Environ Change 2007; 17: 420-428

[65] Salick J, Fang Z, Byg A. Eastern Himalayan alpine plant ecology, Tibetan ethnobotany, and climate change. Global Environ Change 2009; 19: 147-155

[66] Salick J, Ghimire SK, Fang Z, Dema S, Konchar KM. Himalayan alpine vegetation, climate change and mitigation. J Ethnobiol 2014; 34: 276-293

[67] Brandt JS, Haynes MA, Kuemmerle T, Waller DM, Radeloff VC. Regime shift on the roof of the world: Alpine meadows converting to shrublands in the southern Himalayas. Biol Conserv 2013; 158: 116-127

[68] Loarie SR, Duffy PB, Hamilton H, Asner GP, Field CB, Ackerly DD. The velocity of climate change. Nature 2009; 462: 1052-1055

[69] Huang J, Wang P, Niu Y, Yu H, Ma F, Xiao G, Xu X. Changes in C: N: P stoichiometry modify $\mathrm{N}$ and $\mathrm{P}$ conservation strategies of a desert steppe species Glycyrrhiza uralensis. Sci Rep 2018; 8: 12668 
[70] Zhang JT, Xu B, Li M. Diversity of communities dominated by Glycyrrhiza uralensis, an endangered medicinal plant species, along a precipitation gradient in China. Bot Stud 2011; 52: 493-501

[71] Brinckmann JA. Geographical indications for medicinal plants: globalization, climate change, quality and market implications for geo-authentic botanicals. World J Tradit Chin Med 2015; 1: 16-23

[72] Chen KZ, Song H, Chen R. Licorice Industry in China: Implications for licorice Producers in Uzbekistan. Beijing: International Food Policy Research Institute; 2014

[73] Ogbazghi W, Rijkers AJM, Wessel M, Bongers FJJM. The distribution of the frankincense tree Boswellia papyrifera in Eritrea: the role of environment and land use. J Biogeogr 2006; 33: 524-535

[74] Tolera M, Sass-Klaassen U, Eshete A, Bongers F, Sterck FJ. Frankincense tree recruitment failed over the past half century. Forest Ecol Manage 2013; 304: 65-72

[75] Bongers F, Groenendijk P, Bekele T, Birhane E, Damtew A, Decuyper M, Eshete A, Gezahgne A, Girma A, Khamis MA, Lemenih M, Mengistu T, Ogbazghi W, Sass-Klaassen U, Tadesse W, Teshome M, Tolera M, Sterck FJ, Zuidema PA. Frankincense in peril. Nat Sustain 2019; 2: 602-610

[76] Groenendijk P, Eshete A, Sterck FJ, Zuidema PA, Bongers F. Limitations to sustainable frankincense production: blocked regeneration, high adult mortality and declining populations. J Appl Ecol 2012; 49: 164-173

[77] Lemenih M, Arts B, Wiersum K, Bongers F. Modelling the future of Boswellia papyrifera population and its frankincense production. J Arid Environ 2014; 105: 33-40

[78] Govender N, Trollope WS, Van Wilgen BW. The effect of fire season, fire frequency, rainfall and management on fire intensity in savanna vegetation in South Africa. J Appl Ecol 2006; 43: 748-758

[79] Rodríguez MA, Angueyra A, Cleef AM, van Andel TR. Ethnobotany of the Sierra Nevada del Cocuy-Güicán: climate change and conservation strategies in the Colombian Andes. J Ethnobiol Ethnomed 2018; 14: 34

[80] De Cauwer V, Knox N, Kobue-Lekalake R, Lepetu JP, Ompelege M, Naidoo S, Nott A, Parduhn D, Sichone P, Tshwenyane S, Elizabeth Y, Revermann R. Woodland Resources and Management in southern Africa. In: Revermann R, Krewenka KM, Schmiedel U, Olwoch JM, Helmschrot J, Jürgens $\mathrm{N}$, eds. Climate Change and adaptive Land Management in southern Africa - Assessments, Changes, Challenges, and Solutions. Göttingen \& Windhoek: Klaus Hess Publishers; 2018: 296-308

[81] De Cauwer V, Muys B, Revermann R, Trabucco A. Potential, realised, future distribution and environmental suitability for Pterocarpus angolensis DC in southern Africa. Forest Ecol Manage 2014; 315: 211-226

[82] Mehl JW, Slippers B, Roux J, Wingfield MJ. Botryosphaeriaceae associated with Pterocarpus angolensis (kiaat) in South Africa. Mycologia 2011; 103 : 534-553

[83] Schmidhuber J, Tubiello FN. Global food security under climate change. Proc Natl Acad Sci U S A 2007; 104: 19703-19708

[84] IPCC. Climate Change 2014: Synthesis Report. Contribution of Working Groups I, II and III to the Fifth Assessment Report of the Intergovernmental Panel on Climate Change [Core Writing Team, Pachauri RK, and Meyer LA, editors]. Geneva: IPCC; 2014

[85] Ren Z, Wang D, Ma A, Hwang J, Bennett A, Sturrock HJW, Fan J, Zhang W, Yang D, Feng X, Xia Z, Zhou XN, Wang J. Predicting malaria vector distribution under climate change scenarios in China: Challenges for malaria elimination. Sci Rep 2016; 6: 20604

[86] Wayne P, Foster S, Connolly J, Bazzaz F, Epstein P. Production of allergenic pollen by ragweed (Ambrosia artemisiifolia L.) is increased in CO2-enriched atmospheres. Ann Allergy Asthma Immunol 2002; 8: 279-282

[87] Chapman DS, Makra L, Albertini R, Bonini M, Páldy A, Rodinkova V, Šikoparija B, Weryszko-Chmielewska E, Bullock JM. Modelling the introduction and spread of non-native species: international trade and climate change drive ragweed invasion. Global Change Biol 2016; 22: 3067-3079
[88] Frei T. The effects of climate change in Switzerland 1969-1996 on airborne pollen quantities from hazel, birch and grass. Grana 1998; 37 : 172-179

[89] Ziello C, Sparks TH, Estrella N, Belmonte J, Bergmann KC, Bucher E, Brighetti MA, Damialis A, Detandt M, Galán C, Gehrig R, Grewling L, Gutiérrez Bustillo AM, Hallsdóttir M, Kockhans-Bieda MC, De Linares C, Myszkowska D, Pàldy A, Sánchez A, Smith M, Thibaudon M, Travaglini A, Uruska A, Valencia-Barrera RM, Vokou D, Wachter R, de Weger LA, Menzel A. Changes to airborne pollen counts across Europe. PLoS One 2012; 7 : e34076

[90] Zhang Y, Bielory L, Georgopoulos PG. Climate change effect on Betula (birch) and Quercus (oak) pollen seasons in US. Int J Biometeorol 2014; 58: 909-919

[91] McLachlan JS, Hellmann JJ, Schwartz MW. A framework for debate of assisted migration in an era of climate change. Conserv Biol 2007; 21 : 297-302

[92] Williams MI, Dumroese RK. Preparing for climate change: forestry and assisted migration. J Forest 2013; 111: 287-297

[93] Welch RM, Graham RD. Breeding for micronutrients in staple food crops from a human nutrition perspective. J Exp Bot 2004; 55: $353-$ 364

[94] Davis DR. Declining fruit and vegetable nutrient composition: What is the evidence? HortScience 2009; 44: 15-19

[95] Bøhn T, Cuhra M, Traavik T, Sanden M, Fagan J, Primicerio R. Compositional differences in soybeans on the market: glyphosate accumulates in Roundup Ready GM soybeans. Food Chem 2014; 153: 207-215

[96] Figàs MR, Prohens J, Raigón MD, Fita A, Garcia-Martinez MD, Casanova C, Borràs D, Plazas M, Andújar I, Soler S. Characterization of composition traits related to organoleptic and functional quality for the differentiation, selection and enhancement of local varieties of tomato from different cultivar groups. Food Chem 2015; 187: 517-524

[97] Mountain Research Initiative EDW Working Group. Elevation-dependent warming in mountain regions of the world. Nat Clim Chang 2015; 5: 424-430

[98] Turner NJ, Deur D, Mellott CR. “Up on the mountain”: Ethnobotanical importance of montane sites in Pacific coastal North America. J Ethnobiol 2011; 31: 4-43

[99] Nchabeleng L, Mudau FN, Mariga IK. Effects of chemical composition of wild bush tea (Ahtrixia phylicoides DC.) growing at locations differing in altitude, climate and edaphic factors. Med Plants Res 2012; 6: 1662 1666

[100] Ganzera M, Guggenberger M, Stuppner H, Zidorn C. Altitudinal variation of secondary metabolite profiles in flowering heads of Matricaria chamomilla cv. BONA. Planta Med 2008; 74: 453-457

[101] Spitaler R, Winkler A, Lins I, Yanar S, Stuppner H, Zidorn C. Altitudinal variation of phenolic contents in flowering heads of Arnica montana cv. ARBO: a 3-year comparison. J Chem Ecol 2008; 34: 369-375

[102] Albert A, Sareedenchai V, Heller W, Seidlitz HK, Zidorn C. Temperature is the key to altitudinal variation of phenolics in Arnica montana L. CV. ARBO. Oecologia 2009; 160: 1-8

[103] Selmar D, Kleinwächter M. Influencing the product quality by deliberately applying drought stress during the cultivation of medicinal plants. Ind Crops Prod 2013; 42: 558-566

[104] Al-Gabbies A, Kleinwächter M, Selmar D. Influencing the contents of secondary metabolites in spice and medicinal plants by deliberately applying drought stress during their cultivation. Jordan J Biol Sci 2015; 8: 1-10

[105] Maranz S, Wiesman Z. Influence of climate on the tocopherol content of shea butter. J Agric Food Chem 2004; 52: 2934-2937

[106] Chung IM, Kim J], Lim JD, Yu CY, Kim SH, Hahn SJ. Comparison of resveratrol, SOD activity, phenolic compounds and free amino acids in Rehmannia glutinosa under temperature and water stress. Environ Exp Bot 2006; 56: 44-53 
[107] Jochum GM, Mudge KW, Thomas RB. Elevated temperatures increase leaf senescence and root secondary metabolite concentrations in the understory herb Panax quinquefolius (Araliaceae). Am J Bot 2007; 94 : 819-826

[108] Nowak M, Manderscheid R, Weigel J], Kleinwächter M, Selmar D. Drought stress increases the accumulation of monoterpenes in sage (Salvia officinalis), an effect that is compensated by elevated carbon dioxide concentration. J Appl Bot Food Qual 2010; 83: 133-136

[109] Ghasemzadeh A, Jaafar HZE, Rahmat A. Elevated carbon dioxide increases contents of flavonoids and phenolic compounds, and antioxidant activities in Malaysian young ginger (Zingiber officinale Roscoe) varieties. Molecules 2010; 15: 7907-7922

[110] Zhu C, Zeng Q, McMichael A, Ebi KL, Ni K, Khan AS, Zhu J, Liu G, Zhang $X$, Cheng L, Ziska LH. Historical and experimental evidence for enhanced concentration of artemisinin, a global anti-malarial treatment, with recent and projected increases in atmospheric carbon dioxide. Clim Change 2015; 132: 295-306

[111] Briske DD, Camp BJ. Water stress increases alkaloid concentrations in threadleaf groundsel (Senecio longilobus). Weed Sci 1982; 30: 106-108

[112] Kirk H, Vrieling K, van der Meijden E, Klinkhamer PGL. Species by environment interactions affect pyrrolizidine alkaloid expression in Senecio jacobaea, Senecio aquaticus, and their hybrids. J Chem Ecol 2010; 36: 378-387

[113] Caldwell CR, Britz S], Mirecki RM. Effect of temperature, elevated carbon dioxide, and drought during seed development on the isoflavone content of dwarf soybean [Glycine max (L) Merrill] grown in controlled environments. J Agric Food Chem 2005; 53: 1125-1129
[114] Canvin DT. The effect of temperature on the oil content and fatty acid composition of the oils from several oil seed crops. Can J Bot 1965; 43: 63-69

[115] Thomas JMG, Boote KJ, Allen LH jr., Gallo-Meagher M, Davis JM. Elevated temperature and carbon dioxide effects on soybean seed composition and transcript abundance. Crop Sci 2003; 43: 1548-1557

[116] Mozaffarian D, Micha R, Wallace S. Effects on coronary heart disease of increasing polyunsaturated fat in place of saturated fat: a systematic review and meta-analysis of randomized controlled trials. PLoS Med 2010; 7: e1000252

[117] Dawczynski C, Kleber ME, März W, Jahreis G, Lorkowski S. Saturated fatty acids are not off the hook. Nutr Metab Cardiovasc Dis 2015; 25: 1071-1078

[118] Wang Q, Afshin A, Yakoob MY, Singh GM, Rehm CD, Khatibzadeh S, Micha R, Shi P, Mozaffarian D; Global Burden of Diseases Nutrition and Chronic Diseases Expert Group (NutriCoDE). Impact of nonoptimal intakes of saturated, polyunsaturated, and trans fat on global burdens of coronary heart disease. J Am Heart Assoc 2016; 5: e002891

[119] Chakraborty S, Newton AC. Climate change, plant diseases and food security: an overview. Plant Pathol 2011; 60: 2-14

[120] Magan N, Medina A, Aldred D. Possible climate-change effects on mycotoxin contamination of food crops pre- and postharvest. Plant Pathol 2011; 60: 150-163

[121] Bebber DP, Ramotowski MAT, Gurr S]. Crop pests and pathogens move polewards in a warming world. Nat Clim Chang 2013; 3: 985-988

[122] Van der Fels-Klerx HJ, Liu C, Battilani P. Modelling climate change impacts on mycotoxin contamination. World Mycotoxin J 2016; 9: 717726
Please note: this article was changed according to the following erratum: In the Endorsements, the name of Rizwana Khanum (Pakistan Museum of Natural History, Islamabad, Pakistan) was written wrong. 